\title{
EQUILIBRIUM
}

Quarterly Journal of Economics and Economic Policy

VOLUME 9 ISSUE 1, 2014

p-ISSN 1689-765X, e-ISSN 2353-3293

www.economic-policy.pl

Zielenkiewicz M. (2014), Institutional Environment in the Context of Development of Sustainable Society in the European Union Countries, "Equilibrium. Quarterly Journal of Economics and Economic Policy", Volume 9, Issue 1, pp. 21-37, DOI: http://dx.doi.org/10.12775/EQUIL.2014.002

\author{
Małgorzata Zielenkiewicz*
}

University of Gdańsk, Poland

\section{Institutional Environment in the Context of Development of Sustainable Society in the European Union Countries}

JEL Classification: $131,010, O 52, P 46, P 48$

Keywords: social welfare, well-being, social development, institutions

\begin{abstract}
For many countries the Industrial Revolution was an opportunity for a dynamic economic development, but it was accompanied by deep social changes. Inequalities between regions have deepened, pollution has increased and also conjunctural fluctuations have intensified. In contemporary view at the social welfare there is a tendency to abandon identifying it with the level of income. Also, the research on the causes of socio-economic success is developing. One of the aspects of the research, which the article refers to, is the role of the institutions (within the meaning of institutional economics) in the socio-economic development. The aim of the paper is to examine the relationship between indicators of institutional environment and indices related to socio-economic development. For the analysis of the institutional environment the indices published by the World Bank under the name of Worldwide Governance Indicators were used. The analysis of socio-economic level of the countries is based on Sustainable Society Index and its components, which include a wide range of factors related to well-being. The analysis was conducted in two stages. The first stage is a general study of the correlation between WGI and SSI for 151 countries from different continents. The second stage includes a more detailed analysis conducted for the European Union, using the cluster method and the
\end{abstract}

(C) Copyright Institute of Economic Research \& Polish Economic Society Branch in Torun Date of submission: March 15, 2013; date of acceptance: November 27, 2013

* Contact: ekomz@ug.edu.pl, Katedra Mikroekonomii, Wydział Ekonomiczny Uniwersytetu Gdańskiego, ul. Armii Krajowej 119/121, 81-824 Sopot, Poland 
analysis of the level of indicators in groups of countries. The study is based on the data from 2010.

\section{Introduction}

The interest of economists in the sources of socio-economic prosperity has a long history in the economic thought and empirical studies. The analysis included in the paper is the part of the wider research on the contemporary causes of the social welfare and well-being (including analysis of public regulation, structural changes in the real sphere, and geopolitical conditions). The analysis conducted in the paper is a part of the phase of setting the package of potential factors that can have an impact on the level of the socioeconomic prosperity. The aim of the paper is to examine the relationship between indicators of institutional environment and indices related to socioeconomic development. The analysis is based on the Worldwide Governance Indicators (as a measure of the institutional environment) and Sustainable Society Index, which includes a wide range of factors related to the wellbeing. The analysis was conducted in two stages. The first stage is a general study of the statistical correlation between WGI and SSI for 151 countries with very different level of institutional and socio-economic development. The second stage includes a more detailed analysis conducted for the European Union, with usage of cluster method and the analysis of the level of indicators in groups of countries. The study is based on the data from 2010.

\section{The Concept and Measurement of Institutional environment}

In the institutional economics there is an increasing number of the research focused on the role of institutions in the functioning and development of socio-economic systems. Institutions have different definitions. The concept was developed by such economist as T. Veblem, J. Commons, D. C. North, W. Mitchell, J. M. Clark and many more (Stankiewicz 2005). Generally. social institutions can be defined as "rules that influence behaviour, and which are meant to provide certain safeguards before we enter into a transaction" (Groenewegen, Spithoven, van den Berg 2012, p. 24). An institutional capacity of society can be analysed in three main dimensions (Kirdina 2003):

- economic (institutions relating to the receipt of resources for reproduction of social agents),

- political (institutions which form the basic structure of decision-making and implementation by the state), 
- ideological (some norms and values meaningful for society and shaping social behaviour).

It is a discursive issue how to measure the institutional conditions (Woźniak 2008). Measuring institutional environment and phenomena connected with social welfare and development isn't easy, but the number of different measures increases. For measuring institutional dimension following indicators can be used:

- Freedom House Index (FHI), constructed in the early 70's., presently calculated for 195 countries. FHI measures global political rights and civil liberties.

- Economic Freedom of the World (EFW), constructed by Fraser Institute, available for about 150 countries, in some cases even since 1970. EWF contains five main dimensions: Size of Government, Legal Structure and Security of Property Rights, Access to Sound Money, Freedom to Trade Internationally, Regulation of Credit, Labour, and Business.

- Index of Economic Freedom (IEF), published by Heritage Foundation since 1995, presently for 185 countries. IEF includes 10 components connected with different dimensions of economic freedom, grouped into four categories: Rule of Law, Limited Government, Regulatory Efficiency, Open Markets.

- Corruption Perceptions Index (CPI), provided by Transparency International since 1995. At present it covers 174 countries. Transparency International constructed also other indicators connected with CPI.

- Worldwide Governance Indicators (WGI), published by the World Bank since 1996. WGI is calculated for 215 countries and contains six main components: Voice and Accountability, Political Stability and Absence of Violence, Government Effectiveness, Regulatory Quality, Rule of Law, Control of Corruption.

- Bertelsmann Stiftung's Transformation Index (BTI), published by private foundation from Germany. BTI uses the data form 2009-2011 and measures the quality of democracy, a market economy and political management in 128 developing and transition countries. BTI is based on 17 criteria grouped in two main indices: Status Index (Democracy Status and Market Economy Status) and Management Index.

- Sustainable Governance Indicators (SGI), also designed by the Bertelsmann Stiftung. SGI were published in 2009 and 2011 for the OECD countries. Criteria are different, but two main indices have the same name as in BTI: Status Index (Quality of Democracy and Policy Performance) and Management Index (Executive Capacity and Executive Accountability).

- World Governance Index (WGI-2), provided by the Forum for a new 
World Governance and calculated for 179 countries. WGI-2 was constructed in 2008 and is based on five main pillars: Peace and Security, Rule of Law, Human Rights and Participation, Sustainable Development, Human Development (François 2008).

The list of the concepts of measures of the institutional issues isn't complete, but these are calculated for a large number of countries and officially published, which allows to conduct comparative studies.

\section{Institutions in the Context of Social Welfare and Well-being}

Prosperity of nations has a long history within economic considerations. As D. Rodrik (2002) concludes, the research on the causes of economic development can be specified in three main fields: 1. geography (which relates to the advantages and disadvantages posed by a country's physical location), 2 . integration (relates to market size, participation in international trade in goods, services, capital, and possibly labour), 3. institutions (the quality of formal and informal socio-political arrangements). Institutional economist rise such issues like transaction costs, shadow economy, corruption, bureaucracy, the role of state and pressure groups, the costs of over-regulation, property rights, including common access property (Stankiewicz 2005). Not all conclusions are obvious. For example, M. Olson (1982) has observed that political stability might slower the rate of growth. Also an impact of institutional changes was considered. B. Heybey and P. Murrell (1999) concluded that in process of transition initial conditions are much more important than policy changes in determining growth performance in the first years of transition. On the other hand. D. Rodrik, A. Subramanian, and F. Trebbi (2002) prove that the impact of the institutional environment has primacy to geopolitical factors as a determinant of growth. According to an economic freedom, there is no agreement that it is beneficial in all areas. Much research has been conducted (Sturm, De Haan 1998, 2000; Carlsson, Lundström 2002, Ayal, Karras 1998; Dawson 2003, Berggren 2003) and the conclusion is that generally political and economic freedom supports growth, but there is a special importance of property rights, a well-functioning legal system, and free competition.

Most of the research focus on the impact of institutional issues on economic growth. However, since the beginning of the debate on social welfare economists have been aware of the role of subjective perception of a prosperity, because social welfare was considered in a form of the utility function of wealth (Acocella 2002, pp. 73-74). Utility is a category which is hard to measure, so for a long time the research were focused mainly on national 
income or other material categories. In the 80 's the first research on relationship between the income and the perception of life satisfaction appeared. The results show that life satisfaction increases together with the increase of income only for the individuals considered within a particular society conditions. The average happiness stays at the same level if the income of all individuals increases, because people compare their situation to the others (Easterlin's paradox). People also adapt quite quickly to the conditions, the good ones as well as the bad ones, and after some time attach less importance to the factors which they used to value. Also, other factors matter, like employment, relationships with others, health, the level of education (people with higher level of educations statistically show higher level of the sense of happiness) and many more (Grabicz 2012, pp. 13-32). Contemporary approach to the social welfare and well-being includes analysing not only the level of income, but also such phenomena as life expectancy, possibilities of personal development, social exclusion, social inequalities (Fitoussi, et al. 2009; Foster et al. 2005). Leaving aside the factors that can't be shaped by formal, public institutions, there is still a great variety of dimensions which have impact on social welfare and well-being. Recently, many indicators have been constructed, e. g. Human Development Index, which measures the factors connected with social and economic conditions and development. It refers to the contemporary view on social welfare and enables the expansion of the research on determinants of socio-economic development.

\section{Measures of Institutional Environment and Socio-economic Development Used in the Analysis}

The research is based on the Worldwide Governance Indicators (WGI) and the Sustainable Society Index (SSI) with its components. These indicators were chosen because of their complexity and the availability of data for a large number of countries. Authors of WGI define governance as "the traditions and institutions by which authority in a country is exercised". The package of WGI contains six indicators - two in each of three dimensions of governance (Kaufmann et al. 2010):

A. The process by which governments are selected, monitored and replaced:

1. Voice and Accountability (the ability of participation in selecting government, freedom of expression and association, free media);

2. Political Stability and Absence of Violence (the probability of destabilization or overthrow of the government by unconstitutional or violent means, including politically motivated violence and terrorism). 
B. The capacity of the government to effectively formulate and implement sound policies:

3. Government Effectiveness (the quality of public and civil services and its independence from political pressures, the quality of policy formulation and implementation, the credibility of the government);

4. Regulatory Quality (the ability of the government to formulate and implement sound policies and regulations that permit and promote private sector development).

C. The respect of citizens and the state for the institutions that govern economic and social interactions among them:

5. Rule of Law (confidence and respect to the rules of society, the quality of contract enforcement, property rights, the police, and the courts, the likelihood of crime and violence).

6. Control of Corruption (petty and grand forms of corruption, and "capture" of the state by elites and private interests).

All indicators are in the range from $-2,5$ to 2,5 and are the results of estimation of 30 different data sources. The World Bank also publishes information about standard error of the estimation. Because WGI are imposed by an error, indicators have been criticized by some researchers and their cognitive value has some limitation (Oman 2007). It is general problem with indicators which refers to the phenomena difficult to measure, but without attempts of measuring it would be hard to concretize the research issues.

Table 1. Components of Sustainable Society Index

\begin{tabular}{|c|c|c|c|c|}
\hline \multirow{9}{*}{ 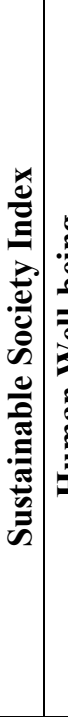 } & & \multirow{3}{*}{ 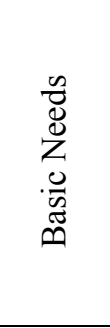 } & 1. Sufficient Food & $\begin{array}{l}\text { Number of undernourished people in \% of } \\
\text { total population }\end{array}$ \\
\hline & & & $\begin{array}{l}\text { 2. Sufficient to } \\
\text { Drink }\end{array}$ & $\begin{array}{l}\text { Number of people as } \% \text { of the total popula- } \\
\text { tion, with sustainable access to an improved } \\
\text { water source. }\end{array}$ \\
\hline & |20.0. & & 3. Safe Sanitation & $\begin{array}{l}\text { Number of people in \% of total population, } \\
\text { with sustainable access to improved sanita- } \\
\text { tion }\end{array}$ \\
\hline & $\sum_{=}^{\bar{c}}$ & \multirow{3}{*}{ 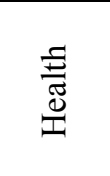 } & 4. Healthy Life & $\begin{array}{l}\text { Life expectancy at birth in number of } \\
\text { healthy life years }\end{array}$ \\
\hline & 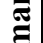 & & 5. Clean Air & Air pollution in its effects on humans \\
\hline & & & 6. Clean Water & Surface water quality \\
\hline & & \multirow{3}{*}{ 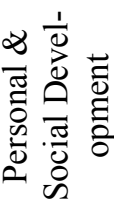 } & 7. Education & $\begin{array}{l}\text { Combined gross enrolment ratio for prima- } \\
\text { ry, secondary and tertiary schools }\end{array}$ \\
\hline & & & 8. Gender Equality & Gender Gap Index \\
\hline & & & $\begin{array}{l}\text { 9. Income Distri- } \\
\text { bution }\end{array}$ & $\begin{array}{l}\text { Ratio of income of the richest } 10 \% \text { to the } \\
\text { poorest } 10 \% \text { of the people in a country }\end{array}$ \\
\hline
\end{tabular}


Table 1 continued

\begin{tabular}{|c|c|c|c|}
\hline & & $\begin{array}{l}\text { 10. Good Gover- } \\
\text { nance }\end{array}$ & $\begin{array}{l}\text { The average of values of the six Govern- } \\
\text { ance Indicators of the World Bank }\end{array}$ \\
\hline \multirow{6}{*}{ 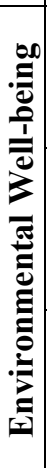 } & \multirow{2}{*}{ 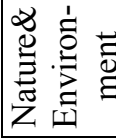 } & 11. Air Quality & Air pollution in its effects on nature \\
\hline & & 12. Biodiversity & Size of protected areas (in \% of land area) \\
\hline & \multirow{2}{*}{ 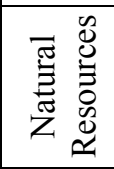 } & $\begin{array}{l}\text { 13. Renewable } \\
\text { Water Resources }\end{array}$ & $\begin{array}{l}\text { Annual water withdrawals ( } \mathrm{m} 3 \text { per capita) } \\
\text { as \% of renewable water resources }\end{array}$ \\
\hline & & 14. Consumption & $\begin{array}{l}\text { Ecological Footprint minus Carbon Foot- } \\
\text { print }\end{array}$ \\
\hline & \multirow{2}{*}{ 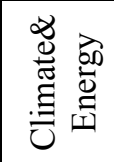 } & $\begin{array}{l}\text { 15. Renewable } \\
\text { Energy }\end{array}$ & $\begin{array}{l}\text { Consumption of renewable energy as } \% \text { of } \\
\text { total energy consumption }\end{array}$ \\
\hline & & $\begin{array}{l}\text { 16. Greenhouse } \\
\text { Gases }\end{array}$ & $\mathrm{CO}_{2}$ emissions per capita per year \\
\hline \multirow{5}{*}{ 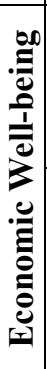 } & \multirow{2}{*}{ : } & $\begin{array}{l}\text { 17. Organic Far- } \\
\text { ming }\end{array}$ & $\begin{array}{l}\text { Area for organic farming in } \% \text { of total } \\
\text { agricultural area of a country }\end{array}$ \\
\hline & & $\begin{array}{l}\text { 18. Genuine } \\
\text { Savings }\end{array}$ & $\begin{array}{l}\text { Genuine Savings (Adjusted Net Savings) as } \\
\% \text { of Gross National Income (GNI) }\end{array}$ \\
\hline & \multirow{3}{*}{$\begin{array}{l}\grave{\Xi} \\
\overline{0} \\
0 \\
0 \\
\text { I }\end{array}$} & $\begin{array}{l}\text { 19. Gross Do- } \\
\text { mestic Product }\end{array}$ & $\begin{array}{l}\text { GDP per capita, PPP, current international } \\
\text { dollars }\end{array}$ \\
\hline & & 20. Employment & Unemployment as \% of total labour force \\
\hline & & 21. Public Debt & $\begin{array}{l}\text { The level of public debt of a country as \% } \\
\text { of GDP }\end{array}$ \\
\hline
\end{tabular}

Source: Sustainable Society Foundation.

For the description of the level of socio-economic development the Sustainable Society Index was used, the indicator constructed by the Sustainable Society Foundation. As Table 1 shows, SSI is based on three pillars: Human Well-being, Environmental Well-being, and Economic Well-being. Next sub-indicators describe 8 of dimensions of sustainable society and these 8 sub-indicators are the result of calculation of another 21 indices. SSF publishes the indices for years 2006, 2008, 2010, 2012 (for 151 countries). All sub-indicators and main indices have values in the range from 0 to 10 .

Because SSI includes WGI (position 10 in table 1), Personal \& Social Development, Human Well-being and main SSI were recalculated without it (as geometric mean, which is the method used in the original calculation of the Sustainable Society Foundation). The SSI used in next part of the paper doesn't include WGI and is based on 20 instead of 21 elements. 


\section{Correlation Between Worldwide Governance Indicators and Sustainable Society Index}

The aim of this part of the research is to examine statistical relationship between WGI and SSI. Because the period of publishing SSI is short, the regression analysis couldn't be done. Instead of it the analysis is based on the greater number of observation (151 countries with very different level of WGI and SSI - full list of the countries is available on SSF website). If there is a correlation, it doesn't mean that good governance is the cause of sustainable development, it only shows that the phenomena coexist. But if phenomena don't coexist, there's no reason for the statement that the level of WGI matters for socio-economic development. The expected result of the analysis is to examine if the level of WGI can be considered as a potential determinant of socio-economic development. Table 2 shows calculations of Pearson's correlation coefficients $(\mathrm{R})$ and coefficients of determination $\left(\mathrm{R}^{2}\right)$ for 151 countries and for the EU (scores in brackets). The data comes from 2010.

According to the worldwide analysis, Environmental Well-being is negatively correlated with all WGI components. Developed countries are those which have also high score in WGI ranking, so pollutions and general poor condition of the natural environment aren't the result of the governance, but of industrialization. Other SSI components are positively correlated with WGI. The highest scores can be observed in the case of Government Effectiveness and Rule of Law, especially for Human Well-being $\left(\mathrm{R}^{2}\right.$ is over $50 \%)$.

Table 2. Pearson's correlation coefficients and coefficients of determination for WGI and SSI (2010)

\begin{tabular}{|l|c|c|c|c|}
\hline $\mathbf{2 0 1 0}$ & $\begin{array}{c}\text { Human } \\
\text { Well-being }\end{array}$ & $\begin{array}{c}\text { Environmental } \\
\text { Well-being }\end{array}$ & $\begin{array}{c}\text { Economic } \\
\text { Well-being }\end{array}$ & $\begin{array}{c}\text { Sustainable } \\
\text { Society Index }\end{array}$ \\
\hline \multicolumn{5}{|c|}{ Voice and Accountability } \\
\hline $\mathrm{R}$ & $0,57(0,53)$ & $-0,27(-0,24)$ & $0,61(0,34)$ & $0,46(0,11)$ \\
\hline $\mathrm{R}^{2}$ & $32 \%(28 \%)$ & $7 \%(6 \%)$ & $37 \%(12 \%)$ & $22 \%(1 \%)$ \\
\hline \multicolumn{5}{|c|}{ Political Stability and Absence of Violence } \\
\hline $\mathrm{R}$ & $0,58(0,23)$ & $-0,37(0,03)$ & $0,58(0,44)$ & $0,33(0,28)$ \\
\hline $\mathrm{R}^{2}$ & $34 \%(5 \%)$ & $14 \%(0 \%)$ & $34 \%(19 \%)$ & $11 \%(8 \%)$ \\
\hline
\end{tabular}


Table 2 continued

\begin{tabular}{|c|c|c|c|c|}
\hline 2010 & $\begin{array}{c}\text { Human } \\
\text { Well-being }\end{array}$ & $\begin{array}{c}\text { Environmental } \\
\text { Well-being }\end{array}$ & $\begin{array}{l}\text { Economic } \\
\text { Well-being }\end{array}$ & $\begin{array}{c}\text { Sustainable } \\
\text { Society Index }\end{array}$ \\
\hline \multicolumn{5}{|c|}{ Government Effectiveness } \\
\hline $\mathrm{R}$ & $0,76(0,54)$ & $-0,51(-0,18)$ & $0,71(0,44)$ & $0,38(0,20)$ \\
\hline $\mathrm{R}^{2}$ & $57 \%(29 \%)$ & $26 \%(3 \%)$ & $50 \%(19 \%)$ & $15 \%(4 \%)$ \\
\hline \multicolumn{5}{|c|}{ Regulatory Quality } \\
\hline $\mathrm{R}$ & $0,68(0,41)$ & $-0,44(-0,28)$ & $0,66(0,37)$ & $0,38(0,07)$ \\
\hline $\mathrm{R}^{2}$ & $47 \%(17 \%)$ & $19 \%(8 \%)$ & $44 \%(14 \%)$ & $14 \%(1 \%)$ \\
\hline \multicolumn{5}{|c|}{ Rule of Law } \\
\hline $\mathrm{R}$ & $0,74(0,44)$ & $-0,51(-0,24)$ & $0,69(0,30)$ & $0,35(0,07)$ \\
\hline $\mathrm{R}^{2}$ & $54 \%(19 \%)$ & $26 \%(6 \%)$ & $47 \%(9 \%)$ & $12 \%(1 \%)$ \\
\hline \multicolumn{5}{|c|}{ Control of Corruption } \\
\hline $\mathrm{R}$ & $0,67(0,52)$ & $-0,45(-0,21)$ & $0,66(0,36)$ & $0,33(0,14)$ \\
\hline $\mathrm{R}^{2}$ & $44 \%(27 \%)$ & $20 \%(4 \%)$ & $43 \%(13 \%)$ & $11 \%(2 \%)$ \\
\hline
\end{tabular}

$\mathrm{R}$ - Pearson's correlation coefficients

$\mathrm{R}^{2}$ - coefficient of determination

In brackets - scores for EU

Source: own calcutations.

The results for the EU countries don't show robust correlation. The EU countries - in global comparison - don't differ as much in the context of institutional environment and the level of socio-economic development. It is also worth of noticing that some of the EU countries went through systemic transformation and the impact of the institutional environment can show the results with a delay. These might be the causes of the lower values of $\mathrm{R}$ and $\mathrm{R}^{2}$ in the EU analysis. According to the calculations, the factor most correlated with Human Well-being is Government Effectiveness, Voice and Accountability and Control of Corruption ( $\mathrm{R}$ over $0,5, \mathrm{R}^{2}$ about $30 \%$ ). Economic Well-being is most correlated (but with results of $\mathrm{R}$ below 0,5) with Government Effectiveness and Political Stability and Absence of Violence $\left(\mathrm{R}^{2}\right.$ about 20\%). 


\section{Institutional Environment and Sustainable Society in the European Union Countries}

This part of the paper focuses on the analysis of the level of SSI and its components in the EU countries. Because correlation for these countries isn't robust, more reasonable might be looking at general stage of development of the institutional conditions and its relation with socio-economic development. The aim of this part of the research is to examine if the countries with developed governance have also high level of indicators connected with socio-economic development.

The EU countries were divided into groups with similar level of WGI with usage of the k-means cluster method. The cluster analysis was based on Euclidean distance for all categories of WGI. The following formula was used:

$$
d\left(x_{i}, x_{k}\right)=d_{i k}=\sqrt{\sum_{j=1}^{p}\left(x_{i j}-x_{k j}\right)^{2}} .
$$

The average distance is the square root of the sum of differences between the value of $j$ characteristic for the objects $x_{i}$ and $x_{k}$ and $p$ is the number of characteristics. Figure 2 shows the stages of creating the clusters. The length of the lines shows the degree of similarity of the countries and groups. The groups were set, when the average distance between all clusters exceeded the value 1.

The most institutionally similar countries are Hungary and Lithuania. There is also a high similarity between the couples Portugal-Slovenia and Bulgaria-Romania. The last couple is relatively very different from all other EU countries and doesn't create a cluster group with them. The countries belonging to the first group are: Sweden, Denmark, Finland, the Netherlands, Luxembourg, Austria, Belgium, France, Germany, Ireland, and The United Kingdom. The countries from the group II are: Hungary, Lithuania, Latvia, Slovakia, Poland, the Czech Republic, Italy, and Greece. The last group includes: Cyprus, Estonia, Malta, Portugal, Slovenia, Spain. None of new EU members aren't in the first group (the group with the highest scores of WGI). Most of the countries form Central-Eastern Europe create the group together with Italy and Greece. These two countries have joined the group as the last ones, but they are more similar (according to WGI level) to Central-Eastern Europe, rather than to other Mediterranean countries. 
Figure 1. Cluster analysis of the EU countries (2010)

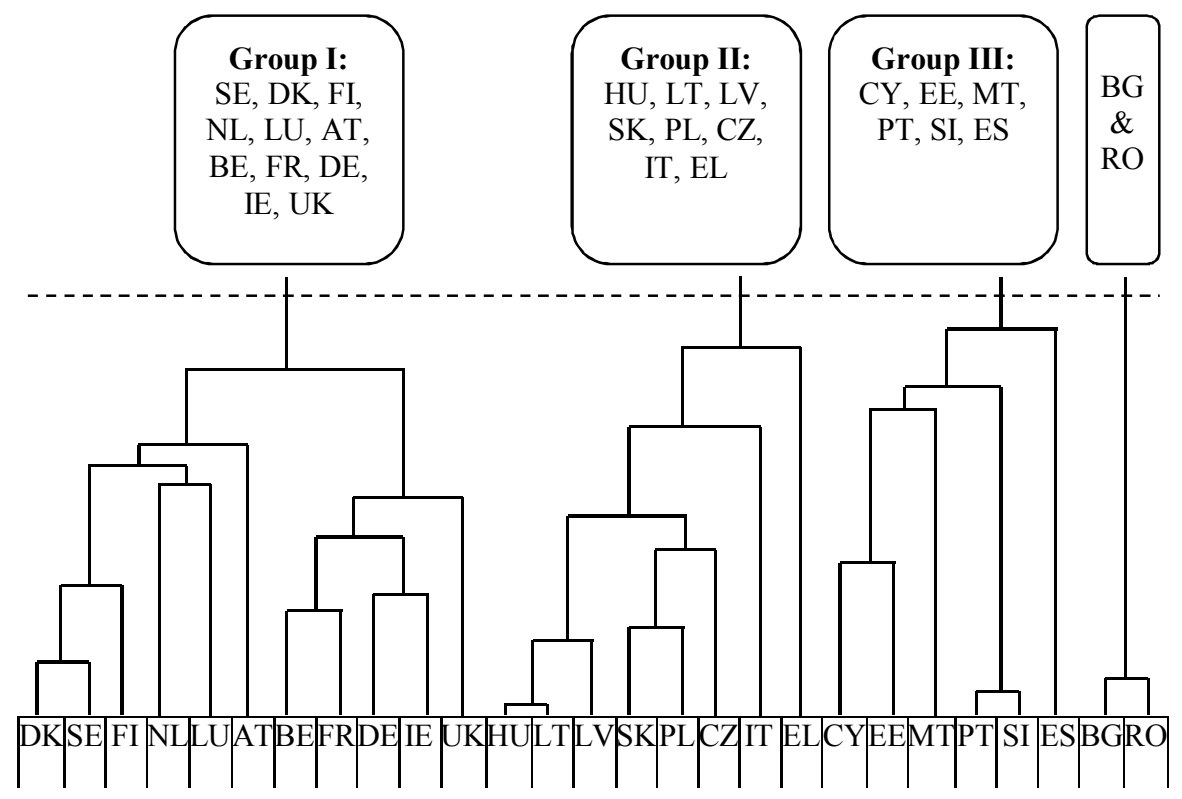

Source: own compilation.

Table 3 shows the average level and standard deviation of WGI in the groups of countries. Most advanced are countries from the first group. All indicators are higher in comparison to the other groups. The second group has week scores, only Political Stability and Absence of Violence is higher than in the third group. Especially Control of Corruption is very low in this group $(0,2)$. The third group has moderate scores, except for Political Stability. Bulgaria and Romania stand out from the EU countries because of very low level of WGI. Government Effectiveness, Rule of Law and Control of Corruption have negative values in these countries.

The absolute leaders in WGI ranking are the Nordic countries. In the first group Belgium and France have the lowest results (an exception is Government Effectiveness - here Ireland has the lowest score). The weakest links in the second group are Italy and Greece. Also, Latvia has relatively low scores. The best results in the group II belongs to the Czech Republic. In the third group, there is no rule. Portugal has one of the highest level of Voice and Accountability within the group, but one of the lowest levels of Regulatory Quality and Rule of Law. Spain's score in Political Stability and Absence of Violence is the lowest in the EU. Slovenia also has relatively poor 
results. Malta seems to have the best governance within the group III, but not in all areas.

Table 3. Average level of WGI in cluster groups of the EU countries

\begin{tabular}{|c|c|c|c|c|c|c|c|}
\hline & & 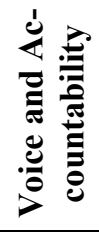 & 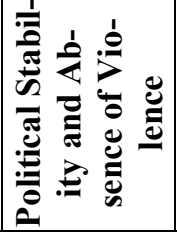 & 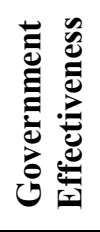 & 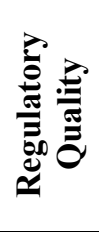 & 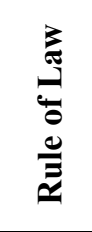 & 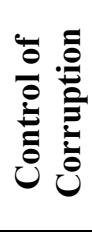 \\
\hline \multirow[t]{2}{*}{ Group I } & Av & 1,43 & 0,98 & 1,74 & 1,64 & 1,76 & 1,86 \\
\hline & $\mathrm{Sd}$ & 0,12 & 0,23 & 0,29 & 0,20 & 0,17 & 0,33 \\
\hline \multirow[t]{2}{*}{ Group II } & Av & 0,92 & 0,66 & 0,71 & 0,97 & 0,69 & 0,20 \\
\hline & $\mathrm{Sd}$ & 0,07 & 0,35 & 0,15 & 0,16 & 0,16 & 0,18 \\
\hline \multirow[t]{2}{*}{ Group III } & $\mathrm{Av}$ & 1,10 & 0,59 & 1,15 & 1,14 & 1,18 & 0,97 \\
\hline & $\mathrm{Sd}$ & 0,05 & 0,40 & 0,17 & 0,31 & 0,15 & 0,08 \\
\hline \multirow[t]{2}{*}{$\mathrm{BG}+\mathrm{RO}$} & Av & 0,46 & 0,32 & $-0,07$ & 0,64 & $-0,01$ & $-0,20$ \\
\hline & $\mathrm{Sd}$ & 0,03 & 0,05 & 0,08 & 0,02 & 0,06 & 0,01 \\
\hline
\end{tabular}

Source: own calculations.

Figure 2 shows the average level of 8 sub-indicators of SSI and Table 4 includes the scores of 20 components of SSI (marked with numbers explained in table 1) and main indices (Human, Environment and Economic Well-being) for extracted groups. SS Indices still don't include WGI (that's why number 10 is missing).

The first group of countries is not only developed in terms of governance, but also has the highest scores in SSI ranking. The exceptions are Natural Resources and Climate and Energy. Results in the second and third group are varied. Group II has the lowest score in Economy, especially in Employment (even Bulgaria and Romania have better results), but - among three groups - leads in the areas connected with an environment. The third group has a low level of Health (mainly problems with clean water), Personal \& Social Development (because of high level of social inequalities), Nature \& Environment, and Transition (especially Genuine Savings). The total SSI is the lowest in the third group. 
Figure 2. The average level of sub-indicators of Sustainable Society Index for cluster groups of the EU countries

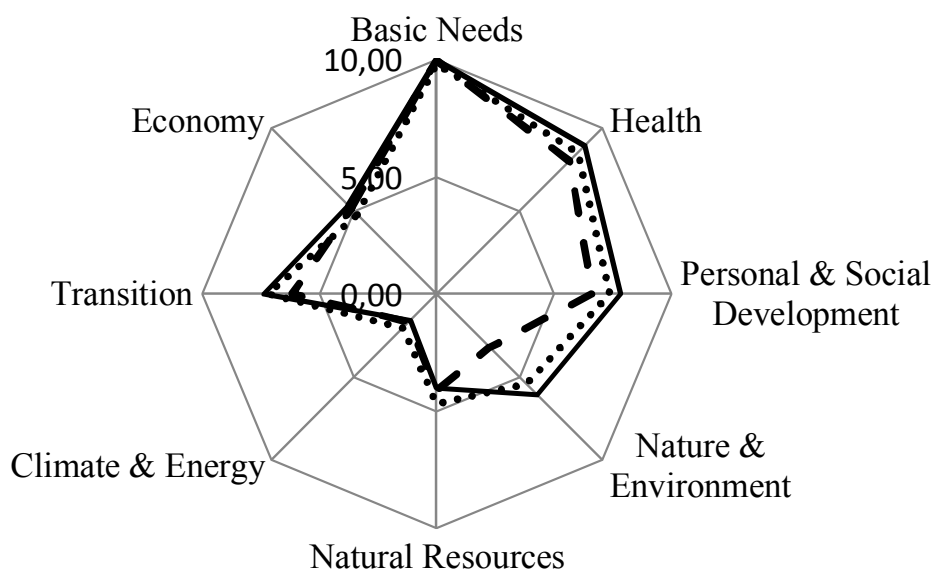

Natural Resources

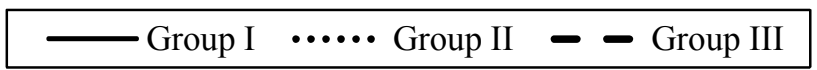

Source: own calculations.

Looking more specifically, the first group isn't very diverse in most dimensions. The exceptions are: Biodiversity (results from 1 in Ireland to 10 in Germany, Luxembourg and Austria), Organic Farming (most developed in Austria and the Nordic countries), and Public Debt - the best situation is in Luxembourg $(9,56)$ and Sweden $(8,31)$, the hardest in Ireland $(1,0)$, Belgium $(1,0)$ Germany $(1,18)$, and France $(1,24)$. These dimensions are also the main areas of differences within group II and III. The countries with biggest problems with Public Debt from the second group are Italy $(1,0)$, Greece $(1,0)$, and Hungary $(1,32)$; from the third one - Portugal $(1,0)$. The countries with best scores are: from group II - Czech Republic, Lithuania, Latvia, Slovakia (over 8,0); from group III - Estonia $(9,91)$ and Slovenia $(8,37)$. In the case of other indicators: all the countries from the first group have GDP index at the level over 9,0, and Genuine Savings over 8,5, only Luxembourg has the lower score of Education (7,55, while the rest of the countries form the group I have at least 9,0), and all the countries from this group has 10 points in dimension connected with basic needs. The lowest level of GDP index in EU are in Bulgaria $(5,98)$, Romania $(5,77)$, Latvia $(6,4)$ and Lithuania $(6,98)$. The biggest problems with employment are in Spain $(1,65)$ and Latvia $(1,77)$. In the EU there are two countries with very low level of Genuine Savings: Greece $(3,11)$, and Portugal $(3,82)$. 
Table 4. The average level of the components of SSI in cluster groups of the EU countries

\begin{tabular}{|l|c|c|c|c|c|c|c|c|}
\cline { 2 - 9 } \multicolumn{1}{c|}{} & $\mathbf{1}$ & $\mathbf{2}$ & $\mathbf{3}$ & $\mathbf{4}$ & $\mathbf{5}$ & $\mathbf{6}$ & $\mathbf{7}$ & $\mathbf{8}$ \\
\hline Grupa I & 10,00 & 10,00 & 9,99 & 8,79 & 10,00 & 8,20 & 9,38 & 7,55 \\
\hline Grupa II & 10,00 & 9,99 & 9,48 & 7,99 & 9,58 & 8,19 & 8,87 & 6,95 \\
\hline Grupa III & 10,00 & 9,93 & 9,92 & 8,43 & 8,85 & 7,46 & 8,90 & 7,02 \\
\hline BG+RO & 9,50 & 9,40 & 8,60 & 7,55 & 8,03 & 8,13 & 8,06 & 6,90 \\
\hline & $\mathbf{9}$ & $\mathbf{1 1}$ & $\mathbf{1 2}$ & $\mathbf{1 3}$ & $\mathbf{1 4}$ & $\mathbf{1 5}$ & $\mathbf{1 6}$ & $\mathbf{1 7}$ \\
\hline Grupa I & 6,90 & 5,89 & 6,73 & 8,97 & 1,90 & 1,54 & 1,80 & 6,36 \\
\hline Grupa II & 6,62 & 4,27 & 7,26 & 8,92 & 2,68 & 1,27 & 3,47 & 7,10 \\
\hline Grupa III & 4,89 & 2,84 & 4,45 & 7,53 & 2,44 & 1,18 & 2,59 & 5,97 \\
\hline BG+RO & 7,50 & 2,66 & 4,15 & 8,40 & 5,72 & 1,18 & 4,63 & 1,76 \\
\hline & $\mathbf{1 8}$ & $\mathbf{1 9}$ & $\mathbf{2 0}$ & $\mathbf{2 1}$ & $\mathbf{H W}$ & $\mathbf{E W}$ & $\mathbf{E W}$ & $\mathbf{S S I}$ \\
\hline Grupa I & 8,89 & 9,35 & 4,88 & 4,13 & $\mathbf{8 , 8 8}$ & $\mathbf{3 , 2 2}$ & $\mathbf{6 , 2 2}$ & $\mathbf{5 , 5 1}$ \\
\hline Grupa II & 7,54 & 7,71 & 3,63 & 5,31 & $\mathbf{8 , 5 1}$ & $\mathbf{3 , 5 7}$ & $\mathbf{5 , 8 3}$ & $\mathbf{5 , 5 5}$ \\
\hline Grupa III & 6,91 & 8,29 & 4,08 & 5,11 & $\mathbf{8 , 0 1}$ & $\mathbf{2 , 7 2}$ & $\mathbf{5 , 5 3}$ & $\mathbf{4 , 8 2}$ \\
\hline BG+RO & 7,72 & 5,87 & 4,72 & 9,31 & $\mathbf{8 , 1 1}$ & $\mathbf{3 , 7 3}$ & $\mathbf{4 , 8 1}$ & $\mathbf{5 , 3 1}$ \\
\hline
\end{tabular}

Source: own calculations.

At the higher level of aggregation: in the first group the lowest score in Economic Well-being is in Ireland $(3,79)$, France $(4,59)$ and Belgium $(4,76)$ - the countries with relatively (within their group) poor level of governance. The best scores are in the Nordic countries and Luxembourg - the countries with highest scores in WGI. Within group II the lowest level in economic dimension can be observed in Greece $(3,77)$, the highest - in the Czech Republic $(7,86)$. In the third group the best economic score is in Slovenia $(7,86)$ and Estonia $(7,11)$, the worst - in Malta $(3,32)$. In Human and Environmental Well-being there are no such big differences within the groups.

\section{Conclusions}

The literature and research raise the importance of the institutional environment for socio-economic development. According to the worldwide analysis the study conducted in the paper shows that:

- Environmental Well-being has negative correlation with WGI (which is rather an apparent correlation connected with industrial development, not 
the governance development);

- Human and Economic Well-being are correlated positively;

- Most correlated with Human and Economic Well-being are Government Effectiveness and Rule of Law, at the second place are Regulatory Quality and Control of Corruption, and least correlated are Political Stability and Absence of Violence, and Voice and Accountability (but still Pearson's correlation coefficients are over 0,5 ).

In the analysis of the EU countries it could be observed that:

- For the EU countries a correlation between WGI and SSI isn't robust, but also institutional diversity of the countries isn't very large and there are countries which are relatively new on the path to a better governance (because of systemic transformation);

- The countries with very high level of WGI are also the countries with the highest level of SSI components connected with Human and Economic Well-being (all group I, especially the Nordic countries);

- None of the countries with low scores in WGI has a good results in Human and Economic Well-being (e.g. Bulgaria, Romania, Italy, Greece).

According to the analysis, it seems that there is a positive relationship between a good governance and socio-economic development, however it is relationship between a general, stable advancement of institutional environment and the stage of human and economic development rather than robust correlation between single indicators. The future research will be focused on other institutional and non-institutional determinants of socio-economic development and the causality analysis for the institutional environment and social welfare.

\section{References}

Acocella N. (2002), Zasady polityki gospodarczej, Wydawnictwo Naukowe PWN, Warszawa.

Ayal E.B., Karras G. (1998), Components of economic freedom and growth: an empirical study, "The Journal of Developing Areas".

Berggren N. (2003), The benefits of economic freedom: a survey, "Independent Review Oakland", Vol. 8, No. 2.

Carlsson F., Lundström S. (2002), Economic freedom and growth: Decomposing the effects, "Public Choice", Vol. 112, No. 3.

Dawson J.W. (2003), Causality in the freedom-growth relationship, "European Journal of Political Economy", Vol. 19, No. 3, http://dx.doi.org/10.1016/S01762680(03)00009-0.

De Haan J., Siermann C.L. (1998), Further evidence on the relationship between economic freedom and economic growth, "Public choice", Vol. 95, No. 3. 
De Haan J., Sturm J.E. (2000), On the relationship between economic freedom and economic growth, "European Journal of Political Economy", Vol. 16, No. 2, http://dx.doi.org/10.1016/S0176-2680(99)00065-8.

Fitoussi J.P., Sen A., Stiglitz J. (2009), Report by the commission on the measurement of economic performance and social progress, The Commission on the Measurement of Economic Performance and Social Progress, http://www.stiglitz-sen-fitoussi.fr/en/index.htm.

Foster J., López-Calva L., Szekely M. (2005), Measuring the Distribution of Human Development: Methodology and an Application to Mexico, "Journal of Human Development and Capabilities", No. 6, http://dx.doi.org/10.1080/146498805 2000342220.

François R. (2008), World Governance Index. Why Should World Governance Be Evaluated, and for What Purpose? Forum for a New World Governance.

Grabicz M. (2012), Problemy rozwoju i zacofania ekonomicznego. Dlaczego jedne kraje sa biedne, podczas gdy inne sa bogate? Wolters Kluwer Polska, Warszawa.

Groenewegen J., Spithoven A., van den Berg A. (2012), Institutional Economics. An Introduction, Palgrave Macmillan, New York, http://dx.doi.org/10.1017/S17441 37407000847.

Heybey B., Murrell, P. (1999), The relationship between economic growth and the speed of liberalization during transition, "The Journal of Policy Reform", Vol. 3, No. 2, http://dx.doi.org/10.1080/13841289908523400.

Kaufmann D., Kraay A., Mastruzzi M. (2010), The Worldwide Governance Indicators - Methodology and Analytical Issues, The World Bank, Development Research Group, Macroeconomics and Growth Team.

Kirdina S.G. (2003), Institutional Matrices and Institutional Changes [in:] Economic Transformation and Evolutionary Theory of J. Schumpeter. The 5th International Symposium on Evolutionary Economics, Moscow.

Olson M. (1982), The rise and Decline of Nations. Economic Growth, Stagflation, and Social Rifiditeis, Yale UniversityPress, London.

Oman Ch. (2007), In Forcus: Governance Indicators and Informal Institutions [in:] J.P. Jütting (ed.), Informal Institutions: How Social Norms Help Or Hinder Development, OECD Publishing.

Rodrik D. (ed.) (2003), Analytic Narratives on Economic Growth, Prinstone University Press, Prinstone.

Rodrik D., Subramanian A., Trebbi F. (2004), Institutions Rule: The Primacy of Institutions over Geography and Integration in Economic Development, "Journal of Economic Growth", Vol. 9, http://dx.doi.org/10.1023/B:JOEG.00000 31425.72248 .85 .

Stankiewicz W. (2005), Ekonomika instytucjonalna. Zarys wykładu, Wydawnictwo Prywatnej Wyższej Szkoły Businessu i Administracji w Warszawie, Warszawa.

Website of Bertelsmann Stiftung on Sustainable Governance Indicators: http://www.sgi-network.de (1.03.2013).

Website of Bertelsmann Stiftung on Transformation Index: http://www.btiproject.org/ (1.03.2013).

Website of Forum for a new World Governance: www.world-governance.org (1.03.2013). 
Website of Fraser Institute: http://www.fraserinstitute.org (1.03.2013).

Website of Freedom House: http://www.freedomhouse.org (1.03.2013).

Website of Heritage Foundation on Index of Economic Freedom: http://www.heritage.org/index/ (1.03.2013).

Website of Sustainable Society Foundation: http://www.ssfindex.com/ (1.03.2013).

Website of Transparency International on Corruption Perceptions Index: http://cpi.transparency.org/cpi2012/ (1.03.2013)..

Website of World Bank on Worldwide Governance Indicators: http://info.worldbank.org/governance/wgi/index.asp (1.03.2013).

Woźniak M.G. (2008), Instytucjonalne uwarunkowania spójności społecznoekonomicznej [in:] D. Kopycińska (ed.), Polityka ekonomiczna państwa we wspótczesnych systemach gospodarczych, Katedra Mikroekonomii, Uniwersytet Szczeciński, Szczecin. 